International Journal of Agriculture, Environment and Bioresearch

Vol. 5, No. 01; 2020

ISSN: $2456-8643$

\title{
EFFECT OF AZOTOBACTER SP. AND COW MANURE (CM) ON HYDROCARBON PETROLEUM DEGRADATION RATE BY USING RAMIE PLANT(BOEHMERIA NIVEA)
}

\author{
Pujawati Suryamana, Ibnu Rizki Perdana, Nadia Nuraniya Kamaluddin, and Mieke Rochimi Setiawati \\ Soil Science and Land Resources, Faculty of Agriculture Universitas Padjadjaran, Raya Jatinangor - Bandung St. \\ KM 21, Indonesia
}

https://doi.org/10.35410/IJAEB.2020.5477

\begin{abstract}
The Petroleum contaminated soil is one of the environment problem which can sharply decrease the soil healthy. A friendly technology that can be used to overcome that problem is Phytoremediation, is a method for removing pollutant by using Plant. In this research was using Ramie (Boehmeria nivea.) as the Phytoremediator. For improving the Rami plant performance to remove hydrocarbon Petroleum was applied Azotobacter sp. and Cow Manure. Azotobacter is the Nitrogen Fixer bacteria that has a role to supply Nitrogen in the rhizophere system. This experiment was focused on to determine the effect of Azotobacter sp. and cow manure (CM) applying on rhizodegradation hydrocarbon petroleum in soil by using Ramie Plants. The experiment was conducted in Green House scale, and the randomized block design was used. The treatments were consist of four treatments (Control; Azotobacter sp; CM dose of $25 \mathrm{~g} / 5 \mathrm{~kg}$ Soil and CM inoculated by Azotobacter sp.). The results showed that the CM dose of $25 \mathrm{~g} / 5 \mathrm{~kg}$ soil treatment could significantly increase the population of Azotobacter spp. of 4.8 x $108 \mathrm{CFU} / \mathrm{g}$ compared Azotobacter sp. treatment. Azotobacter sp. treatment showed tend to increase the degradation of hydrocarbons rate and dry weight of ramie plants were 0.1047 -day and $40.433 \mathrm{~g}$ respectively.
\end{abstract}

Keywords: Azotobacter sp., Cow Manure, Hydrocarbon, Phytoremediation, Ramie.

\section{INTRODUCTION}

Human needs for petroleum energy are increasing every year. The average consumption and production of petroleum in Indonesia on June 2016 increased by 1.615 million barrels per day and 834.4 thousand barrels per day [8]. This is in line with the increase in cases of land pollution due to spills of petroleum waste in various parts of Indonesia. Soil pollution due to factory activities causes 2.2 hectares of land in PT. Unilever Jakarta and 8 Ha at PT. Caltex has been degraded by oil, besides the oil pipeline leak at PT. The $300 \mathrm{~m}$ Connoco Phillips has had an impact on the environment, and many other cases of pollution due to spills of petroleum waste in Indonesia [16]. Phytoremediation is a method of biologically treating waste by using plant for minimizing volume or mobility of toxicity or removing pollutants in soil, groundwater, or other contaminated media [15]. Ramie plants are known as hyperacumulator plants that are tolerant to stressful environments, such as soil contaminated with heavy metals and petroleum hydrocarbons 
[17]. Fitostimulation or rhizodegradation is one of the mechanisms of hyperacumulator plants to repair pollutant contaminated soil by producing root exudates in the form of protein compounds, organic acids, or other compounds needed by soil microbial activity to degrade toxic hydrocarbon compounds [18]. The main obstacle of the nature of contaminated soil is low soil solubility, too high concentration of pollutants, and the lack of adaptability of plants to polluted environmental conditions, causing the results of pollutant degradation to be less effective [2]. Other factors that can inhibit the occurrence of hydrocarbon degradation processes include the influence of oxygen, less optimal soil moisture, too high temperature and light intensity, too low nutrient availability, too high $\mathrm{pH}$ conditions, and very low microbial population on the soil.

Inceptisols from Jatinangor have a low total $\mathrm{N}$ content, this condition has not adequate for the main nitrogen needed for plants in petroleum contaminated soil. Therefore engineering is needed to increase nutrition level in Rhizosphere and to improve root conditions on Soil. Nitrogen-fixing bacteria (BNF) included Azotobacter is biological agents that can fix the di nitrogen (N2) from the air and convert it to ammonia (NH3), which can be synthesized into amino acids, so that plants can be used to grow and develop [1]. Cow manure is known as one type of organic material that can be used on petroleum contaminated soil because it can improve the physical, chemical and biological properties of soil through its role as a source of soil microbial nutrition [13]. The application of BNF (Azotobacter sp.) and cow manure is expected to be able to increase Azotobacter spp. population, hydrocarbon degradation and growth of Ramie plants on petroleum- polluted soil.

\section{MATERIALS AND METHODS}

This research was conducted at the Green House, Ciparanje Experimental Garden, Faculty of Agriculture, Padjadjaran University, Jatinangor, Sumedang, West Java. The height of the research location is around 750 meters above sea level (m asl) with the C3 climate type according to the Oldeman classification. The experimental used order Inseptisol.

Inceptisols Jatinangor, crude oil from Pertamina Balongan Indramayu, clone Ramie plant Lembang, inoculant of Azotobacter sp, collection of Soil Biology Laboratory, Faculty of Agriculture, Padjadjaran University, Ashby's media, cow manure (CM), inorganic fertilizers (urea, SP-36, KCl), and chemicals for calculating Total Petroleum Hydrocarbon (TPH) (nhexane, aquades, and sodium sulfate).

The experimental design used was using a randomized block design with four treatments (control, Azotobacter sp.; CM dose of $25 \mathrm{~g} / 5 \mathrm{~kg}$ of Soil; and CM dose of $25 \mathrm{~g} / 5 \mathrm{~kg}$ of Soil inoculated by Azotobacter sp. 4\% of TPH loading (v/v). Each treatment was carried out in three replications.

\section{Phytoremediation Setup and Sample colection}

The plastic pot was filled by $5 \mathrm{~kg}$ of contaminated soil by $5 \%$ TPH (Total Petroleum Hydrocarbon) of petroleum waste. The petroleum-contaminated soil was set up according to each treatment. Randomized block design (RBD) with four treatments and three replication were used: (1) Natural Attenuation as control, (2) Azotobacter sp (3) Cow manure, 
(4) Cow manure combinated by Azotobacter sp. Each treatment was planted by Ramie plantlet which six week nursery. The Experiment was conducted in the green house scale in condition with the temperature in range of about 27 -

$30 \mathrm{oC}$. Sampling collection was conducted in the interval 2 weeks until TPH content has reached $1 \%$. For enumeration of Azotobacter population sampling $1 \mathrm{~g}$ of soil sample composite were taken, then analysed by serial dilution plate method used Ashby media. While, Hydrocarbon determination was sampled from $10 \mathrm{~g}$ of soil of each treatment, further more soil TPH was analysed by gravimetric method by used n-Hexan as a solvent to extract TPH from sample of soil particle

Data were further analyzed by analysis of variance (ANOVA) followed by Duncan's Significant Multiple Range test (DsMRT) at 5\% confidence level ( $\alpha \leq 0.05$ ANOVA) by SPSS version 16 software for determining significantly of effect of each treatment.

\section{RESULT AND DISCUSSION}

Azotobacter sp. Population in contaminated Soil.

Azotobacter sp. is a species of rhizobacteria that has been known as a biologic fixing N2diazotrof bacteria, which converts dinitrogen to ammonium through electron reduction and protonation of dinitrogen gas.

Table 1.Effect of Addition of Azotobacter sp. and Cow Manure to the Population of Azotobacter sp. at 0 DAAT and 70 DAAT (Day After Aplication Treatment).

\begin{tabular}{|c|c|c|}
\hline \multirow[t]{2}{*}{ Treatment } & \multicolumn{2}{|c|}{$\begin{array}{l}\text { Azotobacter spp. } \\
\text { Population } \\
\left(1^{8} \text { CFU/g Soil }\right)\end{array}$} \\
\hline & $\begin{array}{l}\text { 0 } \\
\text { DAAT }\end{array}$ & $\begin{array}{l}\text { 70 } \\
\text { DAAT }\end{array}$ \\
\hline Control & $0,0071 \mathrm{a}$ & $4,500 \mathrm{ab}$ \\
\hline Azotobacter sp. & $0,0060 \mathrm{a}$ & $2,133 b$ \\
\hline Cow manure $(\mathrm{CM})$ & $0,0120 \mathrm{a}$ & $4,800 \mathrm{a}$ \\
\hline $\begin{array}{l}\text { Azotobacter sp. + } \\
\text { CM }\end{array}$ & $0,0064 \mathrm{a}$ & $3,733 \mathrm{ab}$ \\
\hline
\end{tabular}

Note: Mean values in each column with the same letter are not significantly different $(\mathrm{p}=0.05)$ based on DsMRT. 
Based on the results of the analysis (Table 1.), the population of Azotobacter spp. at 0 Day After Aplication Treatment (DAAT) was encresing after 70 DAAT for each treatment. Increasing the number of bacterial cells that occur is the log phase because indigenous bacteria have adapted to the toxic environment so that they can utilize petroleum as the main carbon source for its growth so that bacteria can carry out cell division as indicated by the population of Azotobacter spp which increases.

The population of Azotobacter spp. during the hydrocarbon biodegradation process within Rhizosphere of Ramie by application CM dose $25 \mathrm{~g} / 5 \mathrm{~kg}$ of Soil increased higher than the other treatments. By adding CM showed that the Azotobacter population was significantly higher than by Azotobacter sp. treatment. This condition proved that Organic material $(\mathrm{CM})$ can induce the growth of Azotobacter spp. in the soil system. This because of Organic material play a role to improve soil characteristic and contribute to supply nutrient for Azotobacter growth. Indigenous species found in petroleum contaminated soil are able to adapt well to toxic environmental conditions, presumably the bacteria are heterotrophic so they are more tolerant to the acidic environment, and grow faster with higher yield in conditions with low Organic material concentrations [20].

The addition of $\mathrm{CM}$ also has an important role in providing sufficient $\mathrm{C} / \mathrm{N}$ for cell growth Azotobacter spp. so that source $\mathrm{C}$ as energy and $\mathrm{N}$ for protein synthesis for growing Azotobacter population becomes available. Meanwhile, the lowest Azotobacter spp. population showed up on the Azotobacter sp. treatment. This phenomenon indicated that Azotobacter exogenous which augmentated to the the soil will occurred competition and inhibition of the Azotobacter growth. And also the petroleum contaminated soil is suspected as the substance which could inhibit Azotobacter spp proliferation. According to [12] research that the Azotobacter spp. abundant in the petroleum contaminated soil after 3th week incubation were declining. The other side Petroleum is hydrophobic substances so that it can lead anaerobic conditions when polluting the soil and disturbing the physical properties of soil aeration [9]. [14] reported that the log phase is an exponential increase in the number of bacterial cells because of the cell continues to divide at a constant rate. Slow growth of Azotobacter spp. by Azotobacter exogenous treatment at start incubating (0 DAAT) was suspected because of Azotobacter sp. exogenous can not use compounds in petroleum for its growth, however, the increase in the number of bacterial cells still occurs at 70 DAA because it is thought to be almost part of Azotobacter sp. was able adapting to the hydrocarbon existing in the soil even thought the increasing of population was not as high as the other treatment. On the other side, it might be happened the cell lyses that leading to contribute nutrients for Azotobacter spp. Meanwhile the enhancement of the number of bacterial cells in the CM treatment showed that the indigenous bacteria found in this study were hydrocarbonoclastic bacteria.

\section{Hydrocarbon Degradation Rate}

The hydrocarbons degradation rate is the magnitude of the molecular weight of hydrocarbons which can be degraded by hydrocarbon degrading microbes within a certain time. 
Vol. 5, No. 01; 2020

ISSN: $2456-8643$

Table 2. Effect of Addition of Azotobacter sp. and Cow Manure to The Rate of Hydrocarbons Degradation during 70 DAAT

\begin{tabular}{|ll|}
\hline \multicolumn{1}{|c|}{ Treatment } & $\begin{array}{l}\text { Hydrocarbons Degradation rate } \\
(\text { (day })\end{array}$ \\
\cline { 2 - 2 } & 0-70 DAAT \\
\hline Control & $0,0838 \mathrm{ab}$ \\
Azotobacter $\mathrm{sp}$. & $0,1047 \mathrm{a}$ \\
Cow Manure $(\mathrm{CM})$ & $0,0838 \mathrm{ab}$ \\
Azotobacter $\mathrm{sp} .+\mathrm{CM}$ & $0,0628 \mathrm{~b}$ \\
\hline
\end{tabular}

Note: Mean values in each column with the same letter are not significantly different $(\mathrm{p}=0.05)$ based on DsMRT.

Based on the results of investigation (Table 2.), the treatment of the bacteria Azotobacter sp. showed the highest hydrocarbon degradation rate compared to the other treatment was a rate of 0.1047 -day. Petroleum components degraded at 70 DAA have a smaller value than the initial incubation stage, this is presumably because the degraded hydrocarbon compounds are in the form of aromatic compounds or toxic metabolic compounds. The decreasing of petroleum hydrocarbons in the soil system can also be caused by the role of Azotobacter sp. which has the ability to produce biosurfactant that function as emulsifiers of petroleum waste so as to support the performance of indigenous microorganisms in removing hydrocarbon compounds [6]. Hydrocarbon Biodegradation rate affected by Cow manure was similar with the rate of Hydrocarbon Biodegradation. This phenomenon showed that indigenous petrophylic in the Ramie rhizosphere was effective to degrade petroleum hydrocarbon as their Carbon source.

By adding Azotobacter sp exogenous within CM showed resulting decreasing rate of petroleum hydrocarbon biodegradation. That might be happened competition among Azotobacter indigenous and Azotobacter sp. inoculated ( exogenous). Availability of nutrients is decreasing while the high number of bacterial cells will cause competition. Increasing competition in utilizing nutirien causes nutrient absorption by bacteria to be increasingly inhibited and did not reach optimal condition. The inhibited growth of bacteria will cause the degradation process of hydrocarbons to slow down and even tend to decrease. [3] reported that too high in abundant of bacterial population will cause nutrient deficiency running faster. Decreasing of nutrient concentration in the soil system can be a barrier to microorganisms in carrying out the degradation process [4]. The intermediate hydrocarbon compounds released during biodegradation process were not further degraded will be accumulated and might be become more toxic for degrader microbes in the soil [6].

Changes in culture conditions caused by substrate transformation can sometimes also cause concentration more toxic to biological agent cultures so that bacteria are difficult to adapt in toxic condition. [11] reported that the level of petroleum solubility is one of the important factors 
that need to be considered to fulfill the readiness of the substrate so that it can be immediately used by soil microorganisms.

Addition of organic matter is important to improve soil structure because it can stimulate polluted soil micro aggregation through organomineral interactions [19]. The addition of CM dose $25 \mathrm{~g} / 5 \mathrm{~kg}$ of soil was thought to have a role as a source of $\mathrm{C}$ for microbes. The availability of organic $\mathrm{C}$ in the growing media also affects the rate of degradation of petroleum hydrocarbons. The low availability of organic $\mathrm{C}$ at the beginning of the petroleum hydrocarbon phytoremediation process can inhibit microbes in breaking down petroleum hydrocarbon chains. This is due to the availability of substrates that are easy to use for limited degrader microbial indigenous growth.

The increasing in hydrocarbon degradation showed that the bacteria used were able to utilize hydrocarbons found in petroleum contaminated soil as a carbon source for bacterial growth accompanied by a high rate of bacterial growth, however the declining rate of hydrocarbon degradation was due to high concentrations of petroleum toxicity produced during the degradation process and the chemical form structure found in the petroleum.

\section{Dry Weight of Ramie Plants}

Observation of plant dry weight is strongly influenced by physiological and environmental factors, so that it can affect the vegetative growth of plants.

Table 3. Effect of Addition of Azotobacter sp. and Cow Manure on Dry Weight of Ramie Plant 77 DAAT.

\begin{tabular}{|ll|}
\hline \multicolumn{1}{|c|}{ Treatment } & $\begin{array}{l}\text { Dry Weight of Ramie Plant } \\
(\text { g) }\end{array}$ \\
\cline { 2 - 2 } & 70 DAAT \\
\hline Control & $28,157 \mathrm{ab}$ \\
Azotobacter $\mathrm{sp}$. & $40,443 \mathrm{a}$ \\
Cow Manure $(\mathrm{CM})$ & $22,543 \mathrm{~b}$ \\
Azotobacter $\mathrm{sp} .+\mathrm{CM}$ & $33,613 \mathrm{ab}$ \\
\hline
\end{tabular}

Note: Mean values in each column with the same letter are not significantly different $(\mathrm{p}=0.05)$ based on DsMRT.

The dry weight of Ramie plants is a parameter that describes the ongoing growth of plants as a result of plant photosynthesis. Based on Table 3., the treatment of Azotobacter sp. showed a significant effect compared to treatment of CM which has the highest dry weight of $40.433 \mathrm{~g} /$ pot. This is presumably because Azotobacter inoculated and Indigenous Azotobacter could exist in petroleum contaminated soil. They were able to adapt in the hydrocarbon petroleum even though the soil was in toxic condition by hydrocarbon existing. The consequent of the Azotobacter adapted was resulting the growth of Ramie plant higher than other treatment. This 
phenomenon might be caused of Azotobacter in that soil system can play a role in releasing the phyitohormone and exopolysaccharide (EPS) to the root of Ramie plant. The same case reported by [10], that Azotobacter spp supplied the phytohormone and exopolysaccharide (EPS) to the rhizosphere, so that it can increase the root growth, and also affecting to the plant water content

The other side, the addition of organic matter decreased the dry weight of ramie plant. This might be happen that the quality of manure used in this research was low, this condition was leading at un-properly doses for plant and so it can cause plants unable to maintain their moisture content, and also can caused the plant will become in N-deficiency. So that resulted reducing plant dry weight. This research result was in line with [5] reported that because organic compounds in too low of $\mathrm{C} / \mathrm{N}$ ratio will also forming ammonia (NH4) gas that is easily lost to the air, caused resulting the $\mathrm{N}$-deficiency in soil system.

\section{CONCLUSION}

The treatment of CM $25 \mathrm{~g} / 5 \mathrm{~kg}$ of soil showed significantly increasing in the Azotobacter spp. population was in amount

$4.8 \times 108 \mathrm{CFU} / \mathrm{g}$. Meanwhile by adding Azotobacter sp. resulted increasing the rate of petroleum hydrocarbons degradation and weight dried plants were 0.1047 -day and $40.433 \mathrm{~g} / \mathrm{pot}$ respectively. Indigenous Azotobacter spp. has well adapting in the Ramie plant during biodegradation of Petroleum hydrocarbon took place.

\section{REFERENCES}

[1]Alexander, M, “Soil Microbiology”. 2nd edition. New York: John Wiley and Sons, Inc.,1977.

[2]Allen, C. C. R, Boyd, D. R., Hempenstall, F., Franklin, M. J., and Sarma, N. D, "Contrasting effect of a nonionic surfactant on the biotransformation of polysiclic aromatic hydrocarbon to cis-dihydrodiols by soil bacterial”. Appl. Environ. Microbiol. 65, pp. 1335-1339, 1998.

[3]Atlas,R.M, "Microbial degradation of petroleum hydrocarbons: an environmental perspective". Microbiological review 45(1), pp. 180-209, 1981.

[4]Ghazali, F.M., R.N.Z.A. Rahman, A.B.Salleh and M.Basri, "Biodegradation of hydrocarbons in soil by microbial consortium". Intl. Biodeteration and Biodegradation 54, pp. 61-67, 2004.

[5]Harada YK, Haga T, Osada, Kashinoa M, "Quality of Compost from Animal Waste". JAQR 26 (4), pp. 238-246, 1993.

[6]Hee, S.B., J.M. Lee and S.T. Lee, "Biodegradation of the mixture of 2,4,6- trichlorophenol, 4chlorophenol, and phenol by a defined mixed culture". Journal of General and Appied Microbiology, 4, pp. 97-103, 1997.

[7] Kepmen LH No. 128. 2003 Tata Cara dan Persyaratan Teknis Pengolahan Tanah Terkontaminasi Minyak Bumi secara Biologis, 3003. 
[8] Ministry of Energy and Mineral Resources, "Indonesian oil production trends" Online:http://migas.esdm.go.id/post/read/produksi-minyak-bumi-terus-meningkat, 2016.

[9] Nwaogu, L.A. Onyeze, G.O.C.and Nwabueze, R.N, "Degradation of diesel oil in polluted soil Bacillus subtilis". African J. of Biotechnology. 7(12), pp. 1939-1943, 2008.

[10]Patel, M. J., Patel, N. M., Patel, R. B., dan Patel, R. P., "Formulation and Evaluation of SelfMicroemulsifying Drug Delivery System of Lovastatin", Asian. J. Pharm. Sci.,5(6), pp 266-267,

[11] Suryatmana, P. 2006. Biodegradasi hidrokarbon minyak bumi dengan penambahan Azotobacter chroococcum AC04 sebagai bakteri penghasil biosurfaktan. Disertasi, Institute Teknologi Bandung Bandung.

[12] Suryatmana, P; Zulkifliani , A M Zannatan , A R Sylvia, M R Setiawati, and Syafrizal, "The potential of the mushroom log waste (MLW) and Azotobactervinelandii to improve hydrocarbon biodegradation for rehabilitation of petroleum contaminated soil". IOP. Confr. Series: Earth and Invionmental Science. 215, pp. 1-8,2018.

[13] Suryatmana, P., Richard A. Gunawan and Mieke R. Setiawati , Diyan Herdiyantoro. "Inokulan Petrofilik dan Kompos Kotoran Ayam dalam Bioremediasi Limbah Minyak Bumi Sistem Land Treatment". Soilrens, 17(1):, pp. 1-8, 2019.

[14] Thiel, T., "Introduction to bacteria". Departement of Biology. University of Missouri St. Louis, pp. 9, 1999.

[15]United States Environmental Protection Agency (USEPA), "Introduction to Phytoremediation". EPA 600/R-99/107, U.S., 2002.

[16]Walhi,“Kompleksitaspersoalansampah”.Online:http://www.walhi.or.id/kampanye/cemar/sa mpah/070528_smph-cu., 2007.

[17] Wei,SH,. Zhou Q X, "Phytoremdiation of cadmiumcontaminated soils by Rorippa globosa using twophase Planting". Environmental Science andPollution Research, 13. pp. 151155, 2006.

[18] Widyati, E, "Kajian fitoremediasi sebagai salah satu upaya menurunkan akumulasi logam akibat air asam tambang pada lahan bekas tambang batu bara". J. Pusat Litbang Hutan dan Konservasi Alam.Tekno Hutan Tanaman 2(2), pp. 67-75, 2009.

[19] Yuan, M., Xu, Z.P., Baumgartil,T., and L. Huang, "Organic mendment and plant growth improved aggregation in Cu/Pb-Zn Tailing”. Soil. Sc. Soc. Am. J. 80 (1), pp 27-37, 2016

[20] Zhao, H.W., Mavinic, D.S., Oldham, W.K., Koch, F.A, "Controlling factors for simultaneous nitrification and denitrifycation in a two-stage intermittent aeration process treating domestic sewage”. Water Resources 33 (4), pp. 961-970. 1999. 